\title{
INVIGORASI BENIH SAWI PAGODA (Brassica narinosa) KADALUARSA DENGAN BERBAGAI KONSENTRASI ZAT PENGATUR TUMBUH ALAMI
}

\author{
Putu Shantiawan Prabawa, I Putu Parmila, Made Suarsana \\ Program Studi Agroteknologi, Fakultas Pertanian, Universitas Panji Sakti \\ Jalan Bisma No. 22, Singaraja, Bali, Indonesia 81116 \\ Email korespondensi: putushantiawan@gmail.com
}

\begin{abstract}
The viability and vigor of tatsoi expired seeds can be improved by invigoration with hydropriming method using natural plant growth regulator (PGR) like cocunut water, shallot extract and aloe vera extract. The purpose of this research was to investigate the effect and type of natural PGR which gave best effect on viability and vigor of the tatsio expired seeds. This research was conducted at the Paranet House of Agriculture Faculty, Panji Sakti University, from March-April 2020. This research was arranged in Randomized Block Design with three replication an if the F-test results were significant followed by LSD test at 5\% level. The treatment tested were: Z0 (Aquades/Control); Z1 (25\% Coconut Water); Z2 (50\% Coconut Water); Z3 (25\% Shallot Extract); Z4 (50\% Shallot Extract); Z5 (25\% Aloe Vera Extract) and Z6 (50\% Aloe Vera Extract). The results showed that natural PGR immersion significantly affected the viability and vigor of tatsoi expired seeds, and the treatment of $50 \%$ coconut water (Z2) gave the best effect.
\end{abstract}

Keywords: invigoration, expired seeds, tatsoi, natural PGR

\begin{abstract}
Abstrak. Benih sawi pagoda yang telah kadaluarsa dapat ditingkatkan viabilitas dan vigornya dengan invigorasi metode hydropriming menggunakan ZPT alami seperti air kelapa, ekstrak bawang merah dan ekstrak daun lidah buaya. Penelitian ini bertujuan untuk mengetahui pengaruh dan jenis ZPT alami yang memberikan efek terbaik pada viabilitas dan vigor benih sawi pagoda kadaluarsa. Penelitian dilaksanakan di Rumah Paranet Fakultas Pertanian Universitas Panji Sakti dari bulan Maret-April 2020. Penelitian disusun dengan Rancangan Acak Kelompok dengan tiga ulangan dan apabila hasil uji $\mathrm{F}$ signifikan dilanjutkan dengan uji BNT pada taraf 5\%. Perlakuan yang diuji adalah: Z0 (Aquades Tanpa ZPT/Kontrol); Z1 (Air Kelapa 25\%); Z2 (Air Kelapa 50\%); Z3 (Ekstrak Bawang Merah 25\%); Z4 (Ekstrak Bawang Merah 50\%); Z5 (Ekstrak Lidah Buaya 25\%) dan Z6 (Ekstrak Lidah Buaya 50\%). Hasil penelitian menunjukkan perendaman ZPT alami berpengaruh nyata terhadap viabilitas dan vigor benih sawi pagoda kadaluarsa, serta perlakuan air kelapa konsentrasi 50\% (Z2) memberikan pengaruh terbaik.
\end{abstract}

Kata kunci: invigorasi, benih kadaluarsa, sawi pagoda, zat pengatur tumbuh alami

\section{PENDAHULUAN}

Penggunaan benih unggul dalam budidaya tanaman sangatlah penting. Benih yang unggul akan meningkatkan kemungkinan hasil panen pada tanaman sawi pagoda (Brassica narinosa). Sawi pagoda merupakan jenis sawi yang memiliki harga cukup tinggi jika dibandingkan jenis sawi lainnya (Arisni, 2019). Benih dapat mengalami penurunan kualitas yang diakibatkan oleh penyimpanan yang kurang tepat atau benih telah melewati masa simpannya (kadaluarsa) (Ernawati et al., 2017).

Penurunan kualitas benih dapat dilihat dari indikator meningkatnya jumlah kecambah yang abnormal, menurunnya daya berkecambah dan penurunan toleransi perkecambahan terhadap kondisi suboptimum (Ilyas, 2012). Penurunan kualitas benih ini dapat diperbaiki dengan beberapa cara diantaranya pemanenan benih pada saat masak fisiologis, prosesing benih secara benar, penyimpanan pada kondisi tempat penyimpanan yang optimal serta bisa juga dengan melakukan invigorasi benih (Utomo, 2006).

Invigorasi benih adalah perlakuan yang diberikan pada benih sebelum penanaman atau penyemaian. Invigorasi benih dapat dilakukan dengan beberapa metode, salah satunya dengan hydropriming (perendaman dalam air), priming dengan berbagai macam larutan dan penambahan matriconditioning (Arief \& Koes, 2010). Invigorasi berbeda dengan pemecahan dormansi, walaupun bahan yang digunakan mungkin sama, misalnya sama-sama zat pengatur tumbuh (ZPT), seperti perendaman biji ulin dalam larutan 
ZPT sodium nitrophenolate (Purba et al., 2019). Pada proses invigorasi selain dengan penggunaan air juga dapat ditambahkan zat lainnya seperti ZPT baik yang alami ataupun sintetis (Ernawati et al., 2017). Perlakuan kombinasi antara lama perendaman dan ZPT juga bisa digunakan untuk invigorasi benih seperti yang dilakukan oleh Srilaba et al. (2018) pada biji tanaman jati.

Bawang merah (Allium cepa L.) dan lidah buaya (Aloe vera) mengandung ZPT alami berupa hormon auksin dan giberilin secara alami. Hormon auksin alami pada bawang merah dapat memacu pertumbuhan akar untuk mempercepat dan memaksimalkan pertumbuhan, sedangkan hormon giberelin dapat menstimulasi pertumbuhan daun dan batang (Lubis et al., 2018). Pada air kelapa (Cocos nucifera) terdapat hormon sitokinin yang mengandung zeatin yang berperan dalam proses pembelahan sel, sehingga umum digunakan pada media kultur jaringan. Perlakuan invigorasi dengan ZPT alami diharapkan memberikan solusi dalam mengembalikan viabilitas dan vigor benihbenih kadaluarsa. Berdasarkan hal tersebut tujuan dilaksanakannya penelitian ini adalah untuk mengetahui pengaruh dan jenis ZPT alami yang memberikan hasil terbaik terhadap viabilitas dan vigor benih sawi pagoda kadaluarsa.

\section{METODE PENELITIAN}

\section{Tempat dan Waktu}

Penelitian ini telah dilaksankan di

Rumah Paranet Fakultas Pertanian, Universitas Panji Sakti Singaraja. Waktu penelitian dimulai dari bulan Maret - April 2020.

\section{Alat dan Bahan}

Alat yang digunakan dalam penelitian ini adalah gelas ukur, spuit (alat suntik), blender, pisau, gunting, gelas plastik, pengaduk, kain kasa untuk menyaring esktrak bawang merah dan ekstrak lidah buaya, penggaris, alat tulis, kantung plastik, nampan plastik dan kamera.

Bahan yang digunakan adalah umbi bawang merah, air kelapa dan daun lidah buaya sebagai zat pengatur tumbuh (ZPT) alami, aquadest, rockwool sebagai media semai benih. Bahan tanam yang digunakan adalah benih sawi pagoda varietas $\mathrm{Ta} \mathrm{Ke}$ Cai yang telah kadaluarsa selama 6 (enam) bulan.

\section{Rancangan Penelitian}

Penelitian ini menggunakan Rancangan Acak Kelompok sederhana dengan tujuh perlakuan dan diulang sebanyak tiga kali. Perlakuan yang diuji dalam penelitian ini adalah: Z0 (Aquades Tanpa ZPT/Kontrol); Z1 (Air Kelapa 25\%); Z2 (Air Kelapa 50\%); Z3 (Ekstrak Bawang Merah 25\%); Z4 (Ekstrak Bawang Merah 50\%); Z5 (Ekstrak Lidah Buaya 25\%) dan Z6 (Ekstrak Lidah Buaya 50\%). Setiap perlakuan diulang tiga kali, sehingga terdapat 21 satuan percobaan.

Data hasil penelitian selanjutnya dianalisis dengan uji $\mathrm{F}$ atau analisis varian (ANOVA) pada taraf 5\% dan apabila menunjukkan ada perbedaan antar perlakuan dilanjutkan dengan Uji Beda Nyata Terkecil (BNT) taraf 5\%.

Penelitian dilakukan dengan metode perendaman pada benih sawi pagoda yang telah kadaluarsa sesuai dengan perlakuan. Benih direndam selama 6 jam, kemudian disemai pada rockwool dan disiram dengan air agar kondisinya lembab. Pengamatan dilakukan setelah benih berkecambah. Parameter pengamatan yang diamati adalah:

1. Umur Berkecambah (hss)

Umur berkecambah benih didapat dengan pengamatan ketika benih telah berkecambah sebanyak $75 \%$ dari total benih.Daya Berkecambah/DB (\%)

Daya berkecambah benih didapat dengan menghitung benih yang berkecambah normal pada hari ke 5 hss dan 7 hss. 
Rumus perhitungan daya berkecambah adalah:

$D B(\%)=\frac{\sum K N \text { Hitungan I }+\sum K N \text { Hitungan II }}{\sum \text { benih yang disemai }} \times 100 \%$

Keterangan:

KN: Kecambah Normal

2. Indeks Vigor/IV (\%)

Pengamatan indeks vigor dilakukan terhadap jumlah kecambah normal pada hitungan pertama (first count), yaitu pada hari ke 5 hss. (ISTA, 2010).

$$
\text { IV }(\%)=\frac{\sum K N \text { Hitungan I }}{\sum \text { benih yang disemai }} \times 100 \%
$$

Keterangan:

KN: Kecambah Normal

3. Keserempakan Tumbuh/KST (\%)

Data keserempakan tumbuh didapat berdasarkan perhitungan persentase kecambah normal pada umur 6 hss. Pengamatan dilakukan terhadap benih normal diantara hitungan pertama dan hitungan kedua. Rumus keserempakan tumbuh adalah:

$$
\text { KST }(\%)=\frac{\sum K N \text { hari ke } 6}{\sum \text { benih yang disemai }} \times 100 \%
$$

Keterangan:

KN: Kecambah Normal

\section{HASIL DAN PEMBAHASAN}

\section{Umur Berkecambah (hss)}

Perendaman berbagai zat pengatur tumbuh (ZPT) alami dengan konsentrasi masing-masing $25 \%$ dan $50 \%$ tidak memberikan pengaruh nyata pada parameter umur berkecambah (Tabel 1). Data pengamatan antara umur berkecambah benih sawi pagoda kadaluarsa yang diberi perlakuan ZPT alami dengan perlakuan kotrol (aquades tanpa ZPT) tidak jauh berbeda yaitu pada perlakuan $\mathrm{Z} 1, \mathrm{Z} 2, \mathrm{Z} 3$, Z4 dan Z6 umur berkecambah adalah 3 hari setelah semai (hss), sedangkan Z0 (kontrol) dan perlakuan Z5 adalah 4 hss (Tabel 2).

Umur berkecambah yang tidak berbeda nyata dapat disebabkan kulit benih sawi pagoda yang tipis, sehingga meskipun hanya direndam dengan aquades tetap terjadi imbibisi ke dalam benih sehingga terjadi pematahan dormansi benih, meskipun terjadi perbedaan namun hanya berbeda 1 hari dibandingkan dengan yang diberi perlakuan ZPT alami.

Menurut Suita \& Bustomi (2014) keras tidaknya kulit benih sangat mempengaruhi proses imbibisi yang juga berdampak pada cepat tidaknya suatu benih untuk berkecambah. Murniati (2013) juga menyatakan bahwa benih yang memiliki kulit yang keras atau dormansi fisik kulit benih (Exogeneous Primary Dormansi) perlu dilakukan skarifikasi mekanik dan kimia, sedangkan pada benih yang kulit benihnya tipis atau tidak memiliki dormansi fisik kulit benih tidak perlu dilakukan skarifikasi fisik dan kimia hanya cukup dilakukan perendaman dengan air saja.

Tabel 1. Rekapitulasi sidik ragam pengaruh perendaman berbagai konsentrasi ZPT alami pada benih

\begin{tabular}{|c|c|c|}
\hline No & Parameter Pengamatan & Nilai rata-rata per parameter \\
\hline 1. & Umur berkecambah (hss) & $3,40^{\operatorname{tn}}$ \\
\hline 2. & Daya Berkecambah (\%) & $71,81^{* *}$ \\
\hline 3. & Indeks Vigor (\%) & $65,52^{* *}$ \\
\hline 4. & Keserempakan Tumbuh (\%) & $61,71^{* *}$ \\
\hline
\end{tabular}
sawi pagoda (Brassica narinosa) kadaluarsa.

Keterangan: **) sangat nyata pada $\mathrm{p} \leq 1 \%$; ) nyata pada $\mathrm{p} \leq 5 \%$; tn) tidak nyata

\section{Daya Berkecambah (\%)}


Hasil analisis varian menunjukkan perendaman benih sawi pagoda kadaluarsa dengan berbagai zat pengatur tumbuh (ZPT) alami berpengaruh sangat nyata terhadap daya berkecambah benih (Tabel 1). Daya berkecambah benih yang diberi perlakuan ZPT alami menunjukkan persentase yang lebih tinggi dibandingkan yang tanpa perlakuan (Z0) dengan Perlakuan perendaman air kelapa dengan konsentrasi 50\% (Z2) memberi pengaruh yang paling signifikan terhadap peningkatan daya berkecambah benih sawi pagoda yang telah kadaluarsa (Tabel 2). Daya berkecambah yang tinggi pada persentase berkecambah hanya $53,33 \%$ (Tabel 2). Daya berkecambah rendah pada benih yang tidak diberi perlakuan disebabkan karena benih yang digunakan telah kadaluarsa. Juanda et al., (2017) menyatakan, benih yang telah kadaluarsa menyebabkan kemampuan benih menurun atau disebut deteorasi yang berdampak pada penurunan mutu, viabilitas dan vigor benih. perendaman air kelapa disebabkan karena air kelapa mengandung mineral, fosfor, kinetin, hormon auksin dan sitokinin yang berfungsi untuk meningkatkan pembelahan sel serta pertumbuhan tunas dan akar tanaman (Fatimah, 2008).

Tabel 2. Rata-rata Umur Berkecambah, Daya Berkecambah, Indeks Vigor dan Keserempakan Tumbuh Benih Sawi Pagoda (Brassica narinosa) Kadaluarsa pada Berbagai Konsentrasi ZPT Alami

\begin{tabular}{lccccccc}
\multicolumn{1}{c}{ Perlakuan } & $\begin{array}{c}\text { Umur } \\
\text { Berkecambah } \\
(\mathrm{hss})\end{array}$ & $\begin{array}{c}\text { Daya } \\
\text { Berkecambah } \\
(\%)\end{array}$ & $\begin{array}{c}\text { Indeks } \\
\text { Vigor } \\
(\%)\end{array}$ & $\begin{array}{c}\text { Keserempakan } \\
\text { Tumbuh } \\
(\%)\end{array}$ \\
\hline Z0 (Aquades Tanpa ZPT/Kontrol) & 4 & 53,33 & a & 53,33 & a & 41,33 & a \\
Z1 (Air Kelapa 25\%) & 3 & 69,33 & b & 66,67 & b & 58,67 & b \\
Z2 (Air Kelapa 50\%) & 3 & 89,33 & d & 80,00 & c & 78,67 & c \\
Z3 (Ekstrak Bawang Merah 25\%) & 3 & 70,67 & b & 65,33 & b & 60,00 & b \\
Z4 (Ekstrak Bawang Merah 50\%) & 3 & 73,33 & c & 65,33 & b & 65,33 & b \\
Z5 (Ekstrak Lidah Buaya 25\%) & 4 & 73,33 & c & 62,67 & b & 62,67 & b \\
Z6 (Ekstrak Lidah Buaya 50\%) & 3 & 73,33 & c & 65,33 & b & 65,33 & b \\
\hline BNT 5\% & tn & $\mathbf{2 , 6 6}$ & $\mathbf{2 , 8 1}$ & $\mathbf{3 , 5 7}$ & \\
\multicolumn{1}{c}{ KK } & $\mathbf{1 2 , 9 1}$ & $\mathbf{3 , 3 3}$ & $\mathbf{3 , 8 5}$ & $\mathbf{5 , 1 9}$ & \\
\hline
\end{tabular}

Keterangan: Bilangan yang didampingi oleh huruf yang sama pada kolom yang sama menunjukkan tidak berbeda nyata berdasarkan uji BNT pada taraf $\mathrm{p}=5 \%$, tn $=$ tidak berbeda nyata, hss $=$ hari setelah semai.

Pengaruh perendaman air kelapa terhadap peningkatan daya berkecambah benih juga dilaporkan oleh Kabelwa \& Soekamto (2017) pada tanaman kedelai yang diberi air kelapa dengan konsentrasi $25 \%, 50 \%$ dan $75 \%$ menunjukkan pengaruh yang nyata dengan meningkatkan daya berkecambah pada tanaman kedelai. Air kelapa juga sering digunakan sebagai ZPT pada propagasi tanaman secara in-vitro. Pemberian air kelapa pada media kultur dengan konsentrasi $30 \%$ menunjukkan pertumbuhan akar dan batang kultur tanaman hazelnut (Corylus avellana) secara signifikan (Prando et al., 2014).

\section{Indeks Vigor (\%)}

Vigor benih adalah sifat benih yang mengindikasikan pertumbuhan dan perkembangan kecambah yang normal, cepat dan seragam pada kondisi lapangan yang optimum dan sub optimum (Ilyas, 2012). Salah satu parameter penilaian vigor benih adalah indeks vigor. 
Data hasil sidik ragam menunjukkan perlakuan perendaman ZPT alami pada benih sawi pagoda kadaluarsa berpengaruh sangat nyata terhadap parameter indeks vigor (Tabel 1). Hal ini menunjukkan pemberian tiga jenis ZPT alami (air kelapa, ekstrak bawang merah dan ekstrak lidah buaya) dapat meningkatkan imbibisi dan memacu pertumbuhan tunas pada benih sawi pagoda yang telah kadaluarsa. Air kelapa, bawang merah dan lidah buaya adalah sumber alami hormon tumbuh yang dapat dipergunakan untuk memacu pembelahan sel dan merangsang pertumbuhan tanaman (Ajar, 2015).

Berdasarkan data tabel 2, perlakuan perendaman benih sawi pagoda kadaluarsa dengan air kelapa konsentrasi 50\% (Z2) menunjukkan pengaruh terbaik terhadap indeks vigor dengan persentase yang tinggi yaitu $80 \%$. Hasil yang sama juga dilaporkan oleh (Ardi et al., 2018) pada benih buah pepaya yang diberi perlakuan $\mathrm{KNO}_{3}$ dan air kelapa 50\% menunjukkan indeks vigor paling baik dibandingkan perlakuan lainnya. Hal ini menandakan air kelapa yang mengandung hormon alami sitokinin dengan konsentrasi $50 \%$ dapat meningkatkan vigor benih yang telah kadaluarsa.

\section{Keserempakan Tumbuh (\%)}

Perlakuan perendaman ZPT alami pada benih sawi pagoda kadaluarsa menunjukkan hasil yang berbeda nyata pada parameter keserempakan tumbuh (Tabel 1). Parameter keserempakan tumbuh menunjukkan kemampuan benih untuk berkecambah secara serempak dengan kondisi normal.

Perlakuan perendaman benih sawi pagoda yang telah kadaluarsa dengan ZPT alami menunjukkan hasil keserempakan tumbuh yang tinggi, hal ini menandakan hormon tumbuh alami yang terdapat pada air kelapa, bawang merah dan lidah buaya sebagai ZPT alami bekerja dengan baik dalam invigorasi benih. Hormon tumbuh yang terdapat pada air kelapa, bawang merah dan lidah buaya merupakan senyawa kimia bukan nutrisi, yang dalam konsentrasi rendah akan mamacu metabolisme dan aktivitas fisiologis benih sehingga menyebabkan terjadinya perkecambahan, pertumbuhan tunas dan akar tanaman (Hidayat \& Yamin, 2018).

Perlakuan perendaman tiga jenis ZPT alami yang diuji menunjukkan perlakuan perendaman dengan air kelapa konsentrasi $50 \% \quad$ (Z2) menunjukkan persentase keserempakan tumbuh kecambah yang paling tinggi yaitu 78,67\% (Tabel 2). Konsentrasi air kelapa yang cukup tinggi yang mengandung hormon tumbuh auksin dan sitokinin (Fatimah, 2008), menyebabkan proses imbibisi pada benih sawi pagoda terjadi secara optimal sehingga keserempakan tumbuh kecambah menjadi tinggi.

Perlakuan air kelapa dengan konsentrasi $10 \%$ - 20\% yang dipadukan dengan Trichoderma terhadap benih cabai (Capsicum annuum L.) kadaluarsa menunjukkan persentase keserempakan tumbuh yang meningkat seiring dengan peningkatan konsentrasi air kelapa (Hasanuddin et al., 2016). Hal ini menandakan perlakuan air kelapa efektif dalam merangsang peningkatan keserempakan tumbuh kecambah pada benih yang kadaluarsa.

\section{SIMPULAN}

Berdasarkan dari hasil penelitian yang telah dilakukan didapatkan kesimpulan bahwa perlakuan invigorasi benih sawi pagoda kadaluarsa menggunakan zat pengatur tumbuh (ZPT) alami menunjukkan adanya pengaruh yang nyata hampir pada semua parameter pengamatan kecuali umur berkecambah benih.

Perlakuan perendaman dengan air kelapa konsentrasi 50\% (Z2) memberikan hasil terbaik pada parameter daya berkecambah, indeks vigor dan keserempakan tumbuh. Oleh sebab itu kedepannya perlu dilakukan pengujian 
pengaruh air kelapa terhadap peningkatan viabilitas dan vigor benih tanaman-tanaman lain yang telah kadaluarsa dengan masa kadaluarsa yang lebih lama dan dapat dikombinasikan dengan zat pengatur tumbuh sintetis atau dengan penggunaan mikroorganisme seperti Trichoderma.

\section{DAFTAR PUSTAKA}

Ajar, S. (2015). Pengaruh Konsentrasi Air Kelapa dan Lama Perendaman Terhadap Perkecambahan Benih Padi (Oryza sativa L.) Kadaluarsa [Skripsi]. Universitas Teuku Umar, Aceh Barat.

Ardi, D. T., Haryati, \& Ginting, J. (2018). Pemberian KNO3 dan Air Kelapa Pada Uji Viabilitas Benih Pepaya (Carica papaya L.). J. Agroteknologi FP USU, 6(4), 730-737.

Arief, R., \& Koes, F. (2010). Invigorasi Benih. Prosiding Pekan Serealia Nasional, Maros 26-30 Juli, 473-477.

Arisni, F. (2019). Pengaruh Konsentrasi Nutrisi Terhadap Pertumbuhan Sawi Pagoda (Brassica narinosa) dengan Sistem Hidroponik Wick dan Sumbangannya pada Pembelajaran Biologi SMA [Skripsi]. Universitas Sriwijaya, Palembang.

Ernawati, P., Rahardjo, \& Suroso, B. (2017). Respon Benih Cabai Merah (Capsicum annum L.) Kadaluarsa Pada Lama Perendaman Air Kelapa Muda Terhadap Viabilitas, Vigor dan Pertumbuhan Bibit. Jurnal Agritop, 15(1), 71-83.

Fatimah, S. N. (2008). Efektifitas Air Kelapa dan Leri terhadap Pertumbuhan Tanaman Hias Bromelia (Neoregelia carolinae) pada Media yang Berbeda [Skripsi]. Universitas Muhammadiyah Surakarta.

Hasanuddin, Maulidia, F., \& Syamsuddin. (2016). Perlakuan Biopriming Kombinasi Air Kelapa Muda dan Trichoderma terhadap Viabilitas dan Vigor Benih Cabai Kadaluarsa
(Capsicum annuum L.). J. Agrotek Lestari, 2(2), 75-82.

Hidayat, T. R. ., \& Yamin, M. (2018). Aplikasi Perendaman ZPT Terhadap Perkecambahan Benih Kapas (Gossypium hirsutum L.). Prosiding Seminar Nasional. 4(1): 295-451.

Ilyas, S. (2012). Ilmu dan Teknologi Benih Teori dan Hasil-Hasil Penelitian. IPB Press.

ISTA. (2010). International Rules for Seed Testing. International Seed Testing Association.

Juanda, B. ., Mulyani, C., \& Sofiyana. (2017). Pengaruh Masa Kadaluarsa dan Perendaman dalam Air Kelapa terhadap Invigorasi Benih Semangka (Citurullus lunatus Thunb. Matsum. Et Nankai). J. Penelitian Agrosamudra, 4(2), 81-91.

Kabelwa, S., \& Soekamto, M. H. (2017). Pengaruh Air Kelapa Terhadap Perkecambahan Benih Kedelai (Glycine max (L) Merr.). J. Median, 9(2), 9-19.

Murniati, E. (2013). Fisiologi Perkecambahan dan Dormansi Benih (Dasar Ilmu dan Teknologi Benih). IPB Press.

Prando, M. A. ., Chiavazza, A., Fagio, A., \& Contessa, C. (2014). Effect of Coconut Water and Growth Regulator Supplements on In Vitro Propagation of Corylus avellana L. Scientia Horticulturae, 171, 91-94.

Purba, J. H., Sasmita, N., Komara, L. L., \& Nesimnasi, N. (2019). Comparison of seed dormancy breaking of Eusideroxylon zwageri from Bali and Kalimantan soaked with sodium nitrophenolate growth regulator. Nusantara Bioscience, 11(2), 146152.

https://doi.org/10.13057/nusbiosci/n1 10206

Srilaba, N., Purba, J. H., Ayu, I., Utami, S., Fakultas, A., Universitas, P., \& Sakti, P. (2018). Pengaruh Pengupasan Kulit Biji dan Pemberian Atonik terhadap 
Perkecambahan Benih Tanaman

Badung (Garcinia dulcis (Roxb.)

Kurz.). Agro Bali: Agricultural Journal, 1(1), 59-68.

Suita, E., \& Bustomi, S. (2014). Teknik

Peningkatan Daya dan Kecepatan

Berkecambah Benih Pilang. $J$.

Penelitian Hutan Tanaman, 11(1), 45-

52.

Utomo, B. (2006). Ekologi Benih. USU Repository. 